\title{
Central Composite Design to develop a robust RP-TLC/Densitometry method for quantification of Triclosan in cosmetic preparations
}

\author{
Kavitha Jayaseelan and Karunanidhi Santhana Lakshmi
}

\begin{abstract}
The current study was framed with a view to develop a simple, sensitive and a rapid RP-TLC/Densitometry method for quantification of Triclosan (TCS) in various cosmetic preparations available in local market. Moreover, robustness testing was planned to be performed employing Central Composite Design (CCD). The desired chromatographic separation was achieved on RP-TLC/Densitometry plates precoated with Silica gel $60 \mathrm{GF}_{254}$ on Aluminum sheet, employing methanol : glacial acetic acid as mobile phase in the ratio of $7: 3 \mathrm{v} / \mathrm{v}$ and detection was carried out at $281 \mathrm{~nm}$. The mobile phase used gave an excellent symmetrical peak for
\end{abstract}

TCS. The method was found linear over a wide range of 20-140 ng/band. The optimized method was validated by measuring various validation parameters. CCD was employed to check the robustness of the method at three-factor levels. The developed and optimized method was used to quantify TCS in 20 different cosmetic preparations procured from local market. The proposed and developed RP-TLC/Densitometry method can be applied for routine analysis of TCS in cosmetic preparations and can also be extended to the analysis in pharmaceuticals and food products.

Keywords: Central Composite Design, Cosmetic preparations, Triclosan, RP-TLC/Densitometry, Validation.
Kavitha Jayaseelan and Karunanidhi Santhana Lakshmi

Department of Pharmaceutical Analysis, SRM College of Pharmacy, SRM University, Kattankulathur, Kancheepuram Dist - 603 203, Tamil Nadu, India.

\section{Corresponding Author:}

Karunanidhi Santhana Lakshmi

e-mail:akshagan0208@gmail.com
Submitted / Gönderilme: 28.01.2017

Accepted / Kabul: $\quad 22.02 .2017$

Revised / Düzeltme: 20.02.2017

\section{INTRODUCTION}

Cosmetics are products, which people use to cleanse or change the look of the face or body and they have become the need of society. Today, make-up plays a vital role for both men and women everywhere. There are many ingredients loading in the cosmetics preparations; TCS is one among them, which was shown to exhibit effective action against different strains of bacteria as well as some fungi and protozoa. It is widely used as an antiseptic, preservative and disinfectant in healthcare and in many consumer products including cosmetics, household cleaning products, plastic materials, toys and paints.

TCS causes antimicrobial resistance and also causes disrupted hormonal development. TCS has more prevalence in soaps, mouthwashes, shampoos, deodorants, toothpastes, cleaning supplies and pesticides [1]. At higher concentration it acts as a biocide with many cytoplasmic and membrane targets. At lower concentration it prevails in commercial products, it acts as bacteriostatic and it targets bacterial fatty acid synthesis [2]. 
The chemical structure of TCS implies that its chemical properties are related to many toxic compounds such Polybrominated diphenyl ethers (PBDEs), Polychlorinated diphenyls (PCBs), Dioxins, Bisphenol A etc., [3]. Data from biological studies have demonstrated that TCS might have endocrine disrupting effects in humans and other animals $[4,5]$. TCS exhibited estrogenic and androgenic activity in both ER- and AR-mediated bioassay [6]. TCS is also reported to have estrogenic activity as it can increase uterine weight in female rats [7]. Hence, its quantification in cosmetics preparations has gained more importance.

Recently, RP-TLC/Densitometry is employed for the quantification of drugs because of its low maintenance cost, less analysis time, minimal consumption of mobile phase per sample, need for simple and easy sample clean-up procedures. Added to the above, it facilitates automated application of sample and scanning of the plate. Moreover, it is flexible enough to analyze different kinds of samples [8].

The design of experiments (DoE) is based on the principles of use of experimental design. Experimental design procedures are very useful in pharmaceutical development including formulation development, analytical method optimization and validation. They are more efficient than the traditional one-variable-at-a-time approach [9].

The literatures collected reveals that there are many analytical methods reported of the estimation of TCS which includes Spectrophotometric [10] and Chromatographic methods like RP-HPLC [11-20], UPLC [21, 22], LC-MS-MS [23-32] and GC-MS [33,34], individually and in combination with other ingredients like Triclocarbon (TCC), Parabens etc.,

The current research article focuses on the determination of robustness of the developed RP-TLC/Densitometry method by CCD and quantification of TCS in cosmetic preparations.
Hence, a modest, rapid, accurate, precise, sensitive, robust and more economical RP-TLC/Densitometry method, with simple sample preparation technique was developed for the estimation and quantification of TCS in various cosmetic preparations, with the aid of CCD design for robustness testing. The general properties of TCS are listed in Table 1.

\section{MATERIALS AND METHODS}

\subsection{Chemicals and reagents employed}

The reference standard of TCS was purchased from SigmaAldrich (India). All other reagents used in the study were procured from Merck Laboratories and S.D. Fine Chemicals Ltd. Double distilled water was utilized throughout the process of analysis. All the cosmetic preparations selected for the analysis were procured from local markets of Chennai.

\subsection{Instruments employed}

The RP-TLC/Densitometry instrument used consisted of the following components: Camag Sample Applicator Linomat5, Twin trough Chamber, Camag Scanner, Camag Document photo. The other apparatus employed for the study includes - Digital balance Sartorius, Ultra Sonic bath sonicator, Centrifuge, Vortexer. Throughout the analysis, all the dilutions were performed employing Class "A" grade glassware's only.

\subsection{Software employed}

WINCATS 5 (Software for handling RP-TLC/Densitometry instrument) was employed. Experimental design, data analysis and desirability function calculations were

Table 1. General Properties of TCS

\begin{tabular}{ccc}
\hline Ingredient & & Characteristics \\
\hline & IUPAC name & 5-Chloro-2-(2,4-diclorophenoxy) phenol \\
TCS & Molecular Formula & Molecular weight \\
& Appearance & $\lambda$ max \\
& Maximum allowable limit in cosmetic product & $289.54 \mathrm{~g} / \mathrm{mol}_{2}$ \\
\hline
\end{tabular}


performed using Design-Expert ${ }^{\circ}$ trial version 7.1.6 (StatEase Inc., Minneapolis) and MS- Excel 2010.

\subsection{Preparation of standard stock solution}

A standard stock solution containing $1 \mathrm{mg} / \mathrm{ml}(1000 \mu \mathrm{g} /$ $\mathrm{ml}$ ) was prepared by dissolving $100 \mathrm{mg}$ of TCS, in $100 \mathrm{ml}$ of methanol. The stock solution was diluted suitably with methanol for further analysis.

\subsection{Preparation of working standard solution}

A series of working standard solutions containing20, 40, 60, $80,100,120$ and $140 \mu \mathrm{g} / \mathrm{ml}$ of TCS was prepared.

\subsection{Chromatographic method development}

Based on various trials carried out, the following chromatographic conditions were optimized for validation. The optimum separation was achieved employing Camag RP-TLC/Densitometry instrument. Camag Twin Through glass chamber (20x10) was used for development which was saturated for 30 mins with the vapors of methanol : glacial acetic acid as mobile phase in the ratio $7: 3 \mathrm{v} / \mathrm{v}$. Linomat $\mathrm{V}$ with Camag $100 \mu \mathrm{l}$ syringe was used to spot $1 \mu \mathrm{l}$ of the prepared standard and spiked sample solutions on RP-TLC/ Densitometry plates (Merk) precoated with Silica gel $60 \mathrm{GF}_{254}$ on Aluminium sheets. They were further dried and subjected to development at ambient temperature. The developed plates were scanned using Camag TLC scanner III at $281 \mathrm{~nm}$ and the obtained densitograms were quantified employing WINCAT Software.

\subsection{Method validation}

Once the method was optimized, it was subjected to various validation parameters to establish the methods validity with respect to linearity, limiting values (LOD and LOQ), precision, accuracy and robustness studies employing design of experiments.

\subsubsection{Linearity}

Concentrations of 20,40,60, 80,100,120 and $140 \mathrm{ng} / \mathrm{band}$ of TCS individually versus their respective peak areas were subjected to linear regression equation to calculate regression and correlation coefficient data.

\subsubsection{Precision}

Intra and inter-day precision studies were carried out by spotting the working standard solution containing $40 \mu \mathrm{g} / \mathrm{ml}$ of TCS and estimating the concentration response six times on the same day (Intra-day) and three different days (Inter-day).

\subsubsection{Accuracy}

The ingredients of known concentrations (at three concentration levels of 20,40 and $140 \mu \mathrm{g} / \mathrm{ml}$ in triplicate) were spiked into the corresponding placebo preparations and extracted employing the similar procedure described under "extraction of TCS from cosmetic preparations". $1 \mu$ l of the extracted solutions were used for further analysis. The percentage recovery was calculated from the average peak area ratio of sample to the standard.

\subsection{Extraction of TCS from cosmetic preparations}

\section{Cosmetic products (20 nos.) including shampoo, soap, toothpaste and creams were purchased from local markets in Chennai}

\section{$5 \mathrm{~g}$ of sample was weighed and the samples were spiked with a series of standard solutions of TCS (Standard addition method)}

\section{$5 \mathrm{ml}$ of methanol was added}

Then diluted to $10 \mathrm{ml}$ and filtered through $0.22 \mu \mathrm{m}$ Millipore membrane filter

The filtrate was used for further analysis. 


\subsubsection{Robustness}

Twenty experiments with six center points were conducted by selection of three factors, methanol content in mobile phase (A), development distance (B), band size (C) and retention factor was selected as the response of TCS at the levels described under Table 5. The nominal value of all these three factors $\mathrm{A}, \mathrm{B}$ and $\mathrm{C}$ were $7 \mathrm{ml}, 8 \mathrm{~cm}$ and $5 \mathrm{~mm}$ respectively. Statistical analysis of ANOVA was performed using Design Expert (Version 7.1.6 Stat-Ease Inc) software.

\section{RESULTS AND DISCUSSION}

Combinations of solvents in different ratios like water, methanol, toluene, acetonitrile, chloroform, ethyl acetate, glacial acetic acid were tried for obtaining a symmetrical peak for TCS. Finally methanol : glacial acetic acid in the ratio $7: 3 \mathrm{v} / \mathrm{v}$, gave a well defined peak for TCS. An increase in the volume of methanol made TCS move towards the solvent front. Inclusion of glacial acetic acid resulted in the occurrence of well-defined peak. The retention time of TCS was found to be $0.49 \pm 0.013$ at the detection wavelength of about $281 \mathrm{~nm}$ (Figure 1).

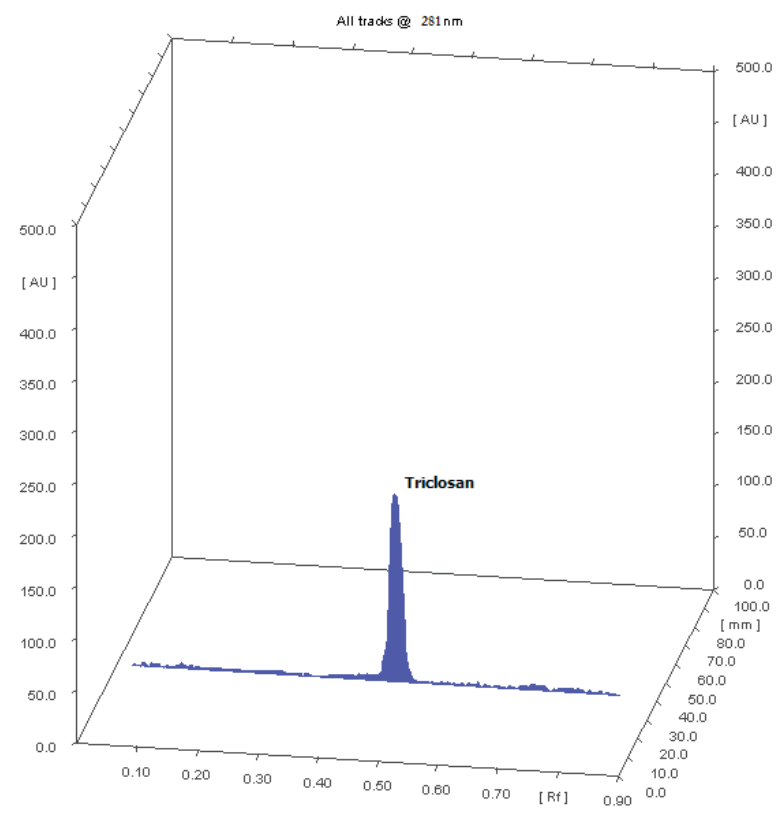

Figure 1. Densitogram of standard solution of TCS

The method showed a good correlation coefficient value of about 0.998 for TCS in the concentration range of $20-140$ $\mathrm{ng} / \mathrm{band}$. The LOD and LOQ values were found to be 0.135 and $0.411 \mathrm{ng} /$ band respectively.
Intra and inter-day precision studies were carried out and the percentage Relative Standard Deviation (\% RSD) was found to be less that $2 \%$ and the results were tabulated in (Table 2).

Table 2. Precision study of TCS

\begin{tabular}{ccccc}
\hline Repeatability & Drug & $\begin{array}{c}\text { Concentration } \\
(\mu \mathrm{g} / \mathrm{ml})\end{array}$ & $\begin{array}{c}\text { Mean } \pm \mathrm{SD})^{*} \\
\mathbf{n}=\mathbf{6}\end{array}$ & \%RSD \\
\hline Intra-day & \multirow{2}{*}{ TCS } & 40 & $\begin{array}{c}101.85 \pm \\
1.51\end{array}$ & 1.24 \\
& & & $102.74 \pm$ \\
Inter-day & \multirow{2}{*}{ TCS } & 40 & 1.71 & 0.95 \\
& & & & \\
\hline
\end{tabular}

${ }^{*}($ Mean $\pm S D)$ of six determinations

Accuracy of the method was performed by standard addition method, at three levels of concentrations in triplicate. The percentage recovery was calculated and was found within the range of 97.0 - $104.0 \% \mathrm{w} / \mathrm{w}$, which suggests the suitability of the method to perform routine analysis of TCS (Table 3 ).

Table 3. Recovery study of TCS from spiked samples

\begin{tabular}{|c|c|c|c|c|c|}
\hline \multirow[b]{2}{*}{ Ingredient } & \multirow{2}{*}{$\begin{array}{c}\text { Spiked } \\
\text { level } \\
(\mu \mathrm{g} / \mathrm{ml})\end{array}$} & \multicolumn{4}{|c|}{$\%$ Recovery (w/w) } \\
\hline & & $\begin{array}{c}\text { Shampoo } \\
(n=3)\end{array}$ & $\begin{array}{l}\text { Soap } \\
(\mathrm{n}=3)\end{array}$ & $\begin{array}{l}\text { Tooth paste } \\
\quad(n=3)\end{array}$ & $\begin{array}{c}\text { Cream } \\
(\mathrm{n}=3)\end{array}$ \\
\hline \multirow{3}{*}{ TCS } & 20 & $101.5 \pm 1.1$ & $100.5 \pm 2.3$ & $99.8 \pm 2.8$ & $97.8 \pm 3.2$ \\
\hline & 40 & $99.2 \pm 3.2$ & $103.1 \pm 2.0$ & $103.8 \pm 1.8$ & $102.5 \pm 3.9$ \\
\hline & 140 & $100.8 \pm 2.9$ & $98.2 \pm 1.7$ & $98.5 \pm 3.2$ & $101.0 \pm 2.1$ \\
\hline
\end{tabular}

${ }^{*}($ Mean $\pm S D)$ of three determinations

The data representing system suitability parameters were listed in Table 4, indicating acceptable precision concerning repeatability of peak area measurement and sample application.

Table 4. System suitability parameters

\begin{tabular}{lc}
\hline \multirow{2}{*}{ Parameters } & Results \\
\cline { 2 - 2 } & TCS \\
\hline Linearity range (ng/band) & $20-140$ \\
Slope & 111.7 \\
\hline Intercept & 18.28 \\
Correlation coefficient ( $\left.\mathbf{r}^{2}\right)$ & 0.998 \\
\hline Retention factor & 0.49 \\
Limit of Detection (ng/band) & 0.135 \\
\hline Limit of Quantification (ng/band) & 0.411 \\
Precision (\% RSD) & $0.95-1.24$ \\
\hline \% Recovery (w/w) & $97.8-104.0$
\end{tabular}


All the experiments designed under CCD model were performed in a randomized manner. The results were tabulated in Table 5.

Table 5. Design of CCD and their response

\begin{tabular}{ccccc}
\hline Run & $\begin{array}{c}\text { A } \\
\text { Organic } \\
\text { Phase } \\
(\mathbf{m l})\end{array}$ & $\begin{array}{c}\text { B } \\
\text { Developing Distance } \\
(\mathbf{c m})\end{array}$ & $\begin{array}{c}\mathbf{C} \\
\text { Band Size } \\
(\mathbf{m m})\end{array}$ & $\begin{array}{c}\mathbf{R}_{\mathrm{f}} \mathbf{\text { of }} \\
\mathbf{T C S}\end{array}$ \\
\hline $\mathbf{1}$ & 5.32 & 8.00 & 5.00 & 0.31 \\
$\mathbf{2}$ & 8.00 & 9.00 & 4.00 & 0.61 \\
$\mathbf{3}$ & 6.00 & 9.00 & 4.00 & 0.41 \\
$\mathbf{4}$ & 6.00 & 7.00 & 4.00 & 0.40 \\
$\mathbf{5}$ & 8.68 & 8.00 & 5.00 & 0.59 \\
$\mathbf{6}$ & 7.00 & 8.00 & 3.32 & 0.50 \\
$\mathbf{7}$ & 6.00 & 7.00 & 6.00 & 0.39 \\
$\mathbf{8}$ & 7.00 & 8.00 & 5.00 & 0.49 \\
$\mathbf{9}$ & 7.00 & 8.00 & 5.00 & 0.49 \\
$\mathbf{1 0}$ & 7.00 & 8.00 & 6.68 & 0.50 \\
$\mathbf{1 1}$ & 7.00 & 6.32 & 5.00 & 0.50 \\
$\mathbf{1 2}$ & 8.00 & 7.00 & 4.00 & 0.60 \\
$\mathbf{1 3}$ & 7.00 & 8.00 & 5.00 & 0.49 \\
$\mathbf{1 4}$ & 8.00 & 9.00 & 6.00 & 0.61 \\
$\mathbf{1 5}$ & 7.00 & 8.00 & 5.00 & 0.49 \\
$\mathbf{1 6}$ & 7.00 & 9.68 & 5.00 & 0.51 \\
$\mathbf{1 7}$ & 6.00 & 9.00 & 6.00 & 0.38 \\
$\mathbf{1 8}$ & 8.00 & 7.00 & 6.00 & 0.60 \\
$\mathbf{1 9}$ & 7.00 & 8.00 & 5.00 & 0.49 \\
$\mathbf{2 0}$ & 7.00 & 8.00 & 5.00 & 0.49 \\
\hline & & & &
\end{tabular}

The experimental results obtained were computed. The polynomial equation model for Y for TCS is tabulated under Table 6. To evaluate the effect of factors selected upon response (retention factor) of TCS, response surface methodology (RSM) and perturbation plots were constructed. Figure 2, depicts the fact that, the change in the content of organic phase (methanol content) has the most significant effect on retention factor. Whereas, the other examined factors like developing distance and bandwidth were not found to have any significant effect on response. Variation in retention factor was observed due to change in the ratio of methanol (increase in methanol content in mobile phase increases the retention factor) content in the mobile phase, which was considered acceptable, as evidence created from the plots and the developed method was reported to be robust.

(A)

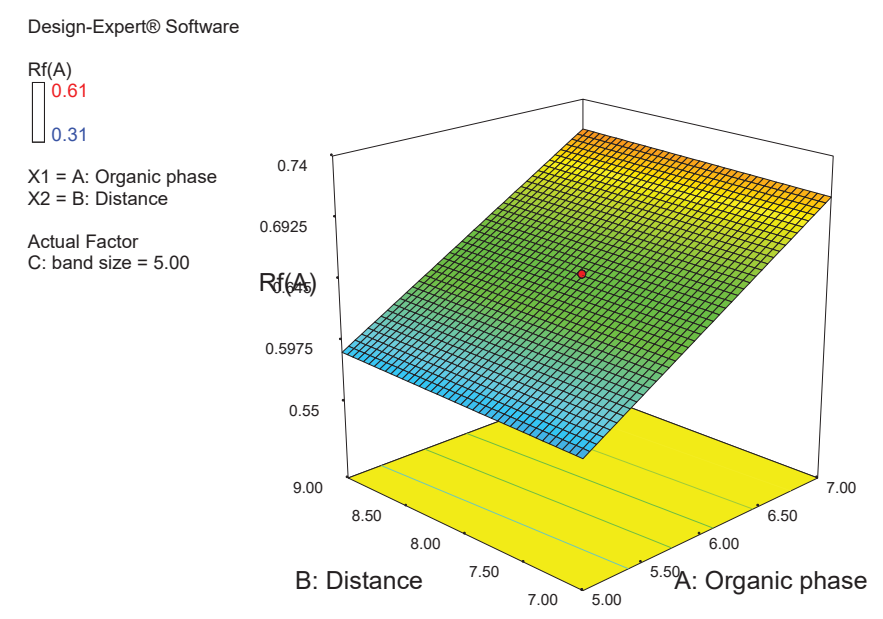

(B)
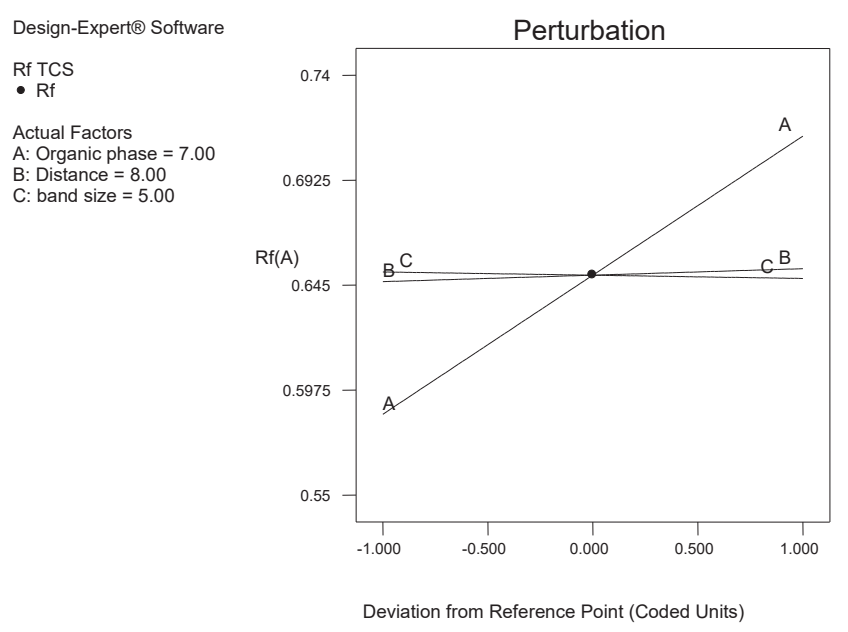

Figure 2. Three-dimensional (3D) plots of the RSM (A) and Perturbation plots (B) for $\mathrm{R}_{\mathrm{f}}$ value of TCS

Employing the optimized method, analysis of TCS in 20 different marketed cosmetic preparations, after extraction was performed and it showed a single peak at $R_{f}$ value of about 0.49 , which was found same as that of the $R_{f}$ value of standard TCS (Figure 3).

Table 6. Predicted Response Models and Statistical Parameters obtained from ANOVA for CCD

\begin{tabular}{cccccc}
\hline $\begin{array}{l}\text { Response } \\
\left(\mathbf{R}_{f} \text { value }\right)\end{array}$ & $\begin{array}{c}\text { Type of } \\
\text { model }\end{array}$ & Polynomial equation model for $\mathbf{Y}$ & $\begin{array}{c}\text { Model } \\
\text { P value }\end{array}$ & $\begin{array}{c}\text { Adequate } \\
\text { Precision }\end{array}$ \\
\hline TCS & Linear & $+0.35+0.00247 \mathrm{~A}+0.012 \mathrm{~B}+0.00542 \mathrm{C}$ & 0.0084 & 2.58 & 33.14 \\
\hline
\end{tabular}




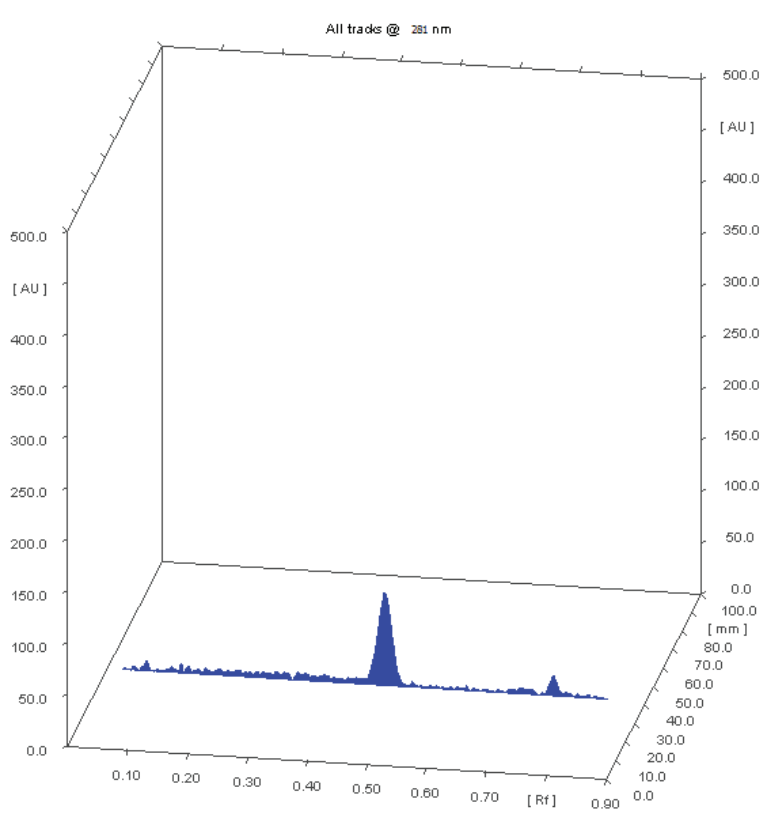

Figure 3. Densitogram of extracted sample (Soap no.1)

The content of TCS in 20 different cosmetic preparations procured from local markets in and around Chennai was calculated after extraction. The obtained results evidently proves that TCS is commonly loaded in most of the cosmetic preparations like shampoo, soap, toothpaste and creams which were selected for analysis. The concentration of TCS predicted was found to lye well below the maximum allowable limit in the cosmetic preparations laid by FDA. (Figure 4)

\section{CONCLUSION}

A well validated RP-TLC/Densitometry method for routine analysis of TCS in cosmetics preparations with the aid of CCD for robustness study has been developed. Moreover the major advantage of RP-TLC/Densitometry method is that several components can be run simultaneously and quantification of compounds can be carried out employing minimal analysis time, using small amount of mobile phase and need for minimum sample clean-up procedure unlike HPLC and other advanced analytical techniques with low maintenance cost per analysis adds up credit to the current study. The application of $\mathrm{CCD}$ on robustness was to examine the variation of different factors simultaneously on the selected response. The robustness study carried out employing CCD, evidence that the change in methanol content in total mobile phase appeared to have a significant effect on the response (retention factor), compared to the other two factors such as development distance and band size selected for the study. Hence, it was important that the significant factor (methanol content in mobile phase) be carefully controlled. It was concluded that the use of experimental design and RSM is a flexible procedure and can be employed to reduce the number of required experiments for robustness study for the developed RP-TLC/Densitometry method. Finally, the developed and validated method allows easy quantification of the TCS in various marketed cosmetic preparations, which was found to be well within the maximum allowable limits for

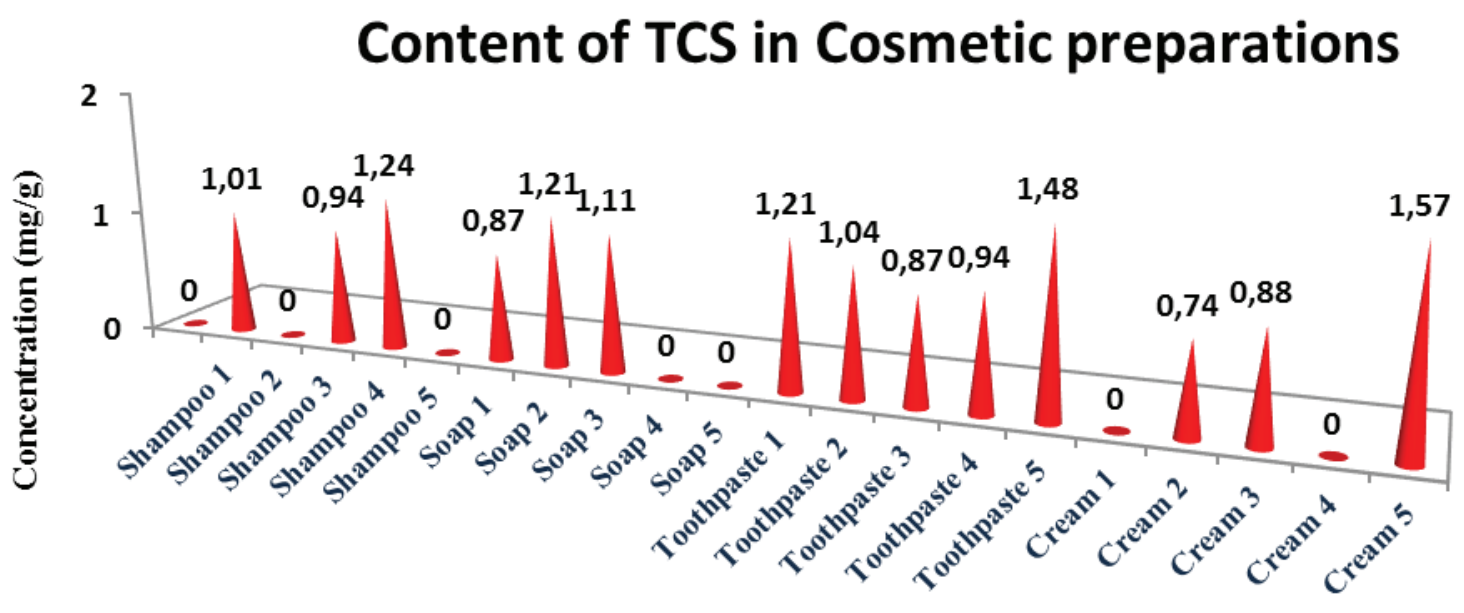

Cosmetic preparations

Figure 4. Content of TCS estimated in the cosmetic preparations (20nos.) 
cosmetics laid by FDA regulations. The method was found to be suitable and repeatable for routine quality control analysis of TCS in cosmetic, food and pharmaceutical products.

\section{DECLARATIONS}

\section{Acknowledgement}

The Authors are grateful to the management of SRM College of Pharmacy, SRM University, for providing necessary facilities to carry out this research work successfully.

\section{Conflict of Interest}

The authors reports on conflict of interest on the study.
Kozmetik preparatların içeriğinde bulunan triklosanın tayini amacıyla güvenilir bir ters faz-ince tabaka kromatografisi/ densitometri yöntemi geliştirmek için merkezi bileşik tasarımın uygulanması

\section{ÖZ}

Bu çalışmada, satışa sunulmuş kozmetik ürünlerde triklosan'ın (TCS) miktar tayini amacıyla kullanıacak basit, hızlı ve duyarlı bir ters faz-ince tabaka kromatografisi/densitometri yöntemi geliştirildi. Geliştirilen yönteme ek olarak elde edilen sistemin sağlamlığının kanıtlanması için yapılan analizlerde merkezi bileşik tasarım (CCD) yöntemi uygulandı. Kromatografik ayrım için silika jel $60 \mathrm{GF}_{254}$ kaplı, ters faz-ince tabaka kromatografisi/ densitometri yöntemi için üretilmiş alüminyum plaklar ve metanol : buzlu asetik 7:3 h/h karışımından oluşan hareketli faz kullanıldı, deteksiyon dalga boyu $281 \mathrm{~nm}$ olarak belirlendi.
Kullanılan hareketli faz TCS için mükemmel simetriye sahip piklerin elde edilmesini sağladı. Yöntem; 2 - 200 ng/band gibi geniş bir aralık için doğrusal olarak tespit edildi. Birçok validasyon parametresi incelenerek yöntem en iyi hale getirildi. Sistemin sağlamlığının kontrolü için üç-faktör düzeyinde CCD yöntemi kullanıldı. Geliştirilen ve en iyi hale getirilen yöntem yerel satıcılardan edinilen 20 farklı kozmetik ürünün içeriğinde bulunan triklosan’ın miktar tayiminin yapılması için kullanıldı. Geliştirilen ters faz-ince tabaka kromatografisi/densitometri yönteminin kozmetik ürünlerde triklosan'ın miktar tayini için rutin olarak kulanılacağı gibi farmasötik ürünlerde ve gıdalarda yapılacak aynı amaçlı analizlerde de kullanımı önerilmektedir.

Anahtar kelimeler: Merkezi Bileşik Tasarım, kozmetik ürünler, Triklosan, ters faz-ince tabaka kromatografisi/densitometri, Validasyon.

\section{REFERENCES}

1. Laurie MG. FDA bans common ingredients in antibacterial soaps and body washes. 2016. Available at; https://www. washingtonpost.com/news/to-your-health/wp/2016/09/02/ fda-bans-some-antibacterial-soaps-and-body-washes/?utm_ term $=.9 \mathrm{db} 49 \mathrm{f} 1663 \mathrm{da}$

2. Russell AD. Whither triclosan? J Antimicrob Chemother 2004; 53: 693-5.

3. Allmyr M, Harden F, Toms LM, Mueller JF, McLachlan MS, Adolfsson-Erici M, Sandborgh-Englund G. The influence of age and gender on triclosan concentrations in Australian human blood serum. Sci Total Environ 2008; 393: 162-7.

4. Foran CM, Bennett ER, Benson WH. Developmental evaluation of a potential non-steroidal estrogen: triclosan. Mar Environ Res 2000; 50: 153-6.

5. Matsumura N, Ishibashi $\mathrm{H}$, Hirano M, Nagao Y, Watanabe N, Shiratsuchi H, Kai T, Nishimura T, Kashiwagi A, Arizono K. Effects of nonylphenol and triclosan on production of plasma vitellogenin and testosterone in male South African clawed frogs (Xenopus laevis). Biol Pharm Bull 2005; 28: 1748-51.

6. Ahn KC, Zhao B, Chen J, Cherednichenko G, Sanmarti E, Denison MS, Lasley B, Pessah IN, Kültz D, Chang DP, Gee SJ, Hammock BD. In vitro biologic activities of the antimicrobials triclocarban, its analogs, and triclosan in bioassay screens: Receptor-based bioassay screens. Environ Health Perspect 2008; 116: 1203-10.

7. Jung EM, An BS, Choi KC, Jeung EB. Potential estrogenic activity of triclosan in the uterus of immature rats and rat pituitary GH3 cells. Toxicol Lett 2012; 208: 142-8.

8. Kaul N, Agrawal H, Paradkar AR, Mahadik KR. HPTLC method for determination of nevirapine in pharmaceutical dosage form. Talanta 2004; 62: 843-52.

9. Swarbrick J. Encyclopedia of Pharmaceutical technology, 1st edition, volme 1. Informa Healthcare Inc, London, UK. 2007, pp 2452-2467.

10. Cabaleiro N, Pena-Pereira F, de la Calle I, Bendicho C, Lavilla I. Determination of TCS by cuvetteless UV-VIS microspectrophotometry following simultaneous ultrasound assisted emulsification-microextraction with derivatization: Use of a micellar-ionic liquid as extractant. Microchem J 2011; 99: 246-51.

11. Liu $\mathrm{T}, \mathrm{Wu} \mathrm{D}$. High-performance liquid chromatographic determination of TCS and triclocarban in cosmetic products. Int J Cos Sci 2012; 34: 489-94.

12. Xie S, Deng H, Xiang B, Xiang S. Detection of trace triclocarban in water sample using solid-phase extraction-liquid 
chromatography with stochastic resonance algorithm. Environ Sci Technol 2008; 42: 2988-91.

13. Guo JH, Li XH, Cao XL, Li Y, Wang XZ, Xu XB. Determination of TCS, triclocarban and methyl-TCS in aqueous samples by dispersive liquid-liquid microextraction combined with rapid liquid chromatography. J Chromatogr A 2009; 1216: 3038-43.

14. Baranowska I, Magiera S, Bortniczuk K. Reverse-phase HPLC method for the simultaneous analysis of TCS and triclocarban in surface waters. Water Sci Technol: Water Supply 2010; 10: 173-80.

15. Scalia S, Guarneri M, Menegatti E. Assay of TCS in deodorant sticks and soaps by supercritical fluid extraction and HPLC. J Soc Cos Chem 1994; 45: 35-42.

16. Verma Kusum S, Kang X. Analysis of TCS and Triclocarban in soil and biosolids using molecularly imprinted solid phase extraction coupled with HPLC-UV. J AOAC Int 2010; 93: 1313-21.

17. Liu Y, Song QJ, Wang L. Development and characterization of an amperometric sensor for TCS detection based on electropolymerized molecularly imprinted polymer. Microchem J 2009; 91: 222-6.

18. Yan H, Wang H, Qin X, Liu B, Du J. Ultrasound-assisted dispersive liquid-liquid micro-extraction for determination of fluoroquinolones in pharmaceutical wastewater. J Pharm Biomed Anal 2011; 54: 53-7.

19. Shen JY, Chang MS, Yang SH, Wu GJ. Simultaneous and rapid determination of TCS, triclocarban and their four related transformation products in water samples using SPMEHPLC-DAD. J Liq Chromatogr Related Technol 2012; 35 : 2280-93.

20. Kim JW, Ramaswamy BR, Chang KH, Isobe T, Tanabe S. Multiresidue analytical method for the determination of antimicrobials, preservatives, benzotriazole UV stabilizers, flame retardants and plasticizers in fish using ultra high performance liquid chromatography coupled with tandem mass spectrometry. J Chromatogr A 2011; 1218: 3511-20.

21. Hong Guo J, Hong Li X, Cao XL, Qu L, Hou DK, Xu XB. Temperature-controlled ionic liquid dispersive liquid phase microextraction combined with ultra-high-pressure liquid chromatography for the rapid determination of TCS, triclocarban and methyl-TCS in aqueous samples. Sci China Chem 2010; 53: 2600-27.

22. Gonzalez-Marino I, Quintana JB, Rodriguez I, Cela R. Simultaneous determination of parabens, TCS and triclocarban in water by liquid chromatography / electrospray ionisation tandem mass spectrometry. J Sep Sci 2009; 23: 1756-66.

23. Asimakopoulosa AG, Wang L, Thomaidis NS, Kannan K. A multi-class bioanalytical methodology for the determination of bisphenol A diglycidyl ethers, p-hydroxybenzoic acid esters, benzophenone-type ultraviolet filters, TCS, and triclocarban in human urine by liquid chromatography-tandem mass spectrometry. J Chromatogr A 2014; 1324: 141-8.

24. Sun J, Yi CL, Zhao RS, Wang X, Jiang WQ, Wang XK. Determination of trace TCS in environmental water by microporous bamboo-activated charcoal solid-phase extraction combined with HPLC-ESI-MS. J Sep Sci 2012; 35 : 2781-6.

25. Quintana JB, Reemtsma T. Sensitive determination of acidic drugs and TCS in surface and wastewater by ion-pair reversephase liquid chromatography/tandem mass spectrometry. Rapid Comm Mass Spect 2004; 18: 765-74.

26. Zhao RS, Wang X, Sun J, Wang SS, Yuan JP, Wang XK. Trace determination of TCS and triclocarban in environmental water samples with ionic liquid dispersive liquid-phase microextraction prior to HPLC-ESI-MS-MS. Anal Bioanal Chem 2010; 397: 1627-33.

27. Shi Y, Liu X, Zhanga J, Shao B. Analysis of TCS and triclocarban in human nails using isotopic dilution liquid chromatography-tandem mass spectrometry. J Chromatogr B 2013; 934: 97-101.

28. Yi CL, Guo WL, Wang XK. Simultaneous determination of triclocarban and TCS in environmental water by using SPE combined with HPLC-ESI-MS. Adv Mat Res 2013; 610:26871.

29. Zhao RS, Wang X, Sun J, Hu C, Wang XK. Determination of TCS and triclocarban in environmental water samples with ionic liquid/ionic liquid dispersive liquid-liquid microextraction prior to HPLC-ESI-MS/MS. Microchim Acta 2011; 174: 145-51.

30. Zhao RS, Wang X, Sun J, Yuan JP, Wang SS, Wang XK. Temperature-controlled ionic liquid dispersive liquid-phase microextraction for the sensitive determination of TCS and triclocarban in environmental water samples prior to HPLCESI-MS/MS. Microchim Acta 2010; 33: 1842-8.

31. Zhao RS, Wang X, Sun J, Hu C, Wang XK. Simultaneous determination of TCS, triclocarban, and transformation products of triclocarban in aqueous samples using solid-phase micro-extraction-HPLC-MS/MS. J Sep Sci 2011; 35: 2544-52.

32. Chu S, Metcalfe CD. Simultaneous determination of triclocarban and TCS in municipal biosolids by liquid chromatography tandem mass spectrometry. J Chromatogr A 2007; 1164: 212-8.

33. Sanchez-Brunete C, Miguel E, Albero B, Tadeo JL. Determination of TCS and methyl TCS in environmental solid samples by matrix solid-phase dispersion and gas chromatography-mass spectrometry. J Sep Sci 2010; 33: 276875.

34. Trenholm RA, Vanderford BJ, Drewes JE, Snyder SA. Determination of household chemicals using gas chromatography and liquid chromatography with tandem mass spectrometry. J Chromatogr A 2008; 1190: 253-62. 